\title{
Reform for reform's sake: A never-ending story of governmental accounting change
}

\author{
Josette Caruana \\ Faculty of Economics, Management and Accountancy, University of Malta, Republic of Malta \\ corresponding e-mail: josette(dot)caruana[at]um(dot)edu\{dot\}mt \\ address: Room 326A, Department of Accountancy, FEMA, University of Malta, Msida MSD 2080, Malta
}

\begin{abstract}
:
This paper applies a qualitative approach to examine the environment surrounding the governmental accounting reform process in Malta using Lüder's Financial Management Reform Process Model. The Governmental accounting reform at central level in Malta is a process that has been going on for over 15 years and is still unfinished business. The issue of a tender in 2014 to acquire a new accounting system was a tangible step towards implementation of accrual accounting, however, uncertainties surround the required funds, the underlying new financial legislation and the applicable financial reporting standards. The case of Malta presents an example of a country that is taking advantage of EU politics in order to gain legitimacy. Given the ceremonial and legitimating features of the reform process, institutional theory is introduced in Lüder's Model, putting forward an integrated model that distinguishes between the demands and effects of the technical and institutional environments. The combination of institutional and contingency theories provides a more holistic understanding of the accounting reform process.
\end{abstract}

JEL Classifications: $\mathrm{H} 83$

Keywords: Contingency theory, governmental accounting reform, institutional theory

Citation: Caruana, J. (2017). Reform for reform's sake: A never-ending story of governmental accounting change. Business and Economic Horizons, 13(5), 676-705, http://dx.doi.org/10.15208/beh.2017.46

\section{Introduction}

Research literature is rich with studies that have applied Institutional theory to explain a range of accounting phenomena. Accounting researchers have used concepts of legitimacy, institutional isomorphism, decoupling, and the notions of power and selfinterest involved in the process of institutionalization of accounting practices, to highlight the institutional pressures that are exerted through the actions of different actors in such process (see for example, Ansari \& Euske, 1987; Burns, 2000; Chalmers \& Godfrey, 2004; Christensen, 2003; Covaleski \& Dirsmith, 1988; Covaleski et al., 1993; Dirsmith et al., 1997; Fogarty, 1996; Geiger \& Ittner, 1996; Granlund \& Lukka, 1998; Gupta et al., 1994; Hussain \& Hoque, 2002; Lapsley \& Pallot, 2000; Rahaman et al., 2004; Rollins \& Bremser, 1997). Institutional theory has assisted in conceptualising the analysis of accounting reform, particularly by focusing on the dynamics of processes of accounting change and the key drivers of that change (see for example, Chung et al., 2000; Fogarty \& Rogers, 2005; Modell, 2003; Tsamenyi et al., 2006).

In the case of the public sector, various studies have found that accounting systems implemented to satisfy government mandates are rarely used for internal decision-making and control (see, for example, Covaleski \& Dirsmith, 1991; Geiger \& Ittner, 1996; ter Bogt \& van Helden, 2000). Geiger \& Ittner (1996, p. 550) concluded that the primary use of elaborate, mandated accounting systems is to legitimize the organization's activities to external constituencies by creating the impression that the organization is well-controlled and that resources are being used rationally. Institutional theory is thus useful to the study of accounting in the contexts in which it operates. It implies that the interests, objectives, and actions of those external to any given organization may also be critically important in 
understanding accounting choice (Carpenter \& Feroz, 1992; Moll et al., 2006). According to Collier (2001, p. 468), accounting systems are one of the most important conventions connecting institutionally defined beliefs systems with technical activities. Accounting techniques can become taken for granted organizational routines, which is consistent with the emphasis of institutional theory on the symbolic and ritualistic properties of rationalformal systems of rules (Power \& Laughlin, 1996, pp. 459-460). Accounting structures are myths which assist to legitimise an organization within its institutional environment, as they lead to the organisation being described as rational in technology and well-controlled (Meyer, 1983, p. 235).

Carruthers (1995), Moll et al. (2006), Ribeiro \& Scapens (2006), and Scapens (2006) described the relevance of institutional theory to accounting research. However, it is necessary to consider the possibility that institutional pressures may operate simultaneously with other forces. This has been demonstrated by accounting research that has combined institutional theory with other theories. For example, Abernethy \& Chua (1996) and Carpenter \& Feroz (2001) combined institutional theory and resource dependency theory; Granlund \& Lukka (1998) combined economic and institutional perspectives; and Gupta et al. (1994) combined contingency theory with institutional theory.

Various models have been developed in an attempt to describe and understand government reforms (see, for example, Greenwood \& Hinings, 1996; Hood, 1995; Ouda, 2011; Pollitt \& Bouckaert, 2004). Based on contingency theory, Lüder's Model (2002) is preferred because it addresses financial management reform in particular. The variables are specific and give more meaning than, for example, Hood's 'motive' and 'opportunity' (Laughlin \& Pallot, 1998). Lüder's Model is not prescriptive like Ouda's. Lüder's explanatory model may be more applicable in a study that is trying to identify the how and why of governmental accounting reform. Accounting reforms are initiated but it may not be the intention of the actors themselves to actually 'reach the end of the tunnel' as prescribed by Ouda (2011, p. 267).

Lüder's Model has been extensively researched (see, for example, Chan, 1994; Chan et al, 1996; Haldma, 2006; Jorge, 2005; Lüder \& Jones, 2003; Monsen \& Näsi, 1998). Jorge (2003) provides a detailed description of how the model evolved over time. Some of the major contributions to the model include Pallot's (1995) consideration of size of the jurisdiction; Godfrey et al.'s (1996) aid distortion; Jaruga \& Nowak's (1996) feedback loops; and Laughlin \& Pallot's (1998) epistemic communities.

Some researchers have found it necessary to refer to other theories when applying Lüder's Model. Jaruga \& Nowak (1996) took into consideration sociological theories to complement contingency theory. Godfrey et al. (2001) combined Lüder's Model with theories of diffusion of innovations to provide a better insight into the social, political, economic and organisational factors affecting the innovation process. In this study, Lüder's Model is combined with Institutional theory resulting in an integrated model that better explains what is happening in the Maltese context.

The case of Malta presents an example of an EU member state that is taking advantage of EU politics in order to gain legitimacy. The accounting system of the Maltese Central Government is cash-based and budget oriented. Central Government accounting reform in Malta has been going on for over 15 years: quite a long tale, with the authors of the story apparently stuck in the introductory chapters. The story is proceeding based on International Public Sector Accounting Standards (IPSAS) because it is not expected that there will be any major differences between IPSAS and European Public Sector Accounting Standards (EPSAS) (Ministry of Finance [MoF], 2013c).

The objective of this paper is to examine the environment surrounding the governmental accounting reform process in Malta using Lüder's Financial Management Reform Process Model (2002). The study identifies the contextual, behavioural and instrumental variables that have affected the change process over time, and analyses why this change process is 
Reform for reform's sake: A never-ending story of governmental accounting change | BEH: www.beh.pradec.eu

being undertaken, how it has developed, and why the process has not yet reached a conclusion. Given the ceremonial and legitimating features of the reform process, institutional theory is combined with contingency theory in Lüder's Model (2002), putting forward an integrated model.

The theoretical contribution of this paper is the development of the integrated contingency-institutional theory model that explains reform processes. This is described in Section 2. The value of this study is enhanced by the quality of the empirical work, described in Sections 3 and 4, that is made possible by the conciseness of the jurisdiction covered in the study. Malta provides an interesting research field with highly accessible government officials. The context of the case study made it easier to identify the factors that are pushing and pulling the reform process in the directions that it has taken over time. Section 5 applies Lüder's Model (2002) to the Maltese context. The analysis in Section 6 applies the suggested integrated model to give a better insight of how and why this accounting reform process has been extended into a never-ending story. Section 7 summarises the study and highlights the importance of the results for other researchers.

\section{Theoretical framework}

\subsection{Lüder's Financial Management Reform Model (2002)}

Lüder's Model (2002) is fundamentally an economic model, embodying a supply and demand framework for government financial information (Chan et al., 1996, p. 3). The attitudes and behaviours of users and producers of governmental financial information are shaped by their respective environments (Chan et al., 1996, p. 3). Given the right environment, the interactions between demand and supply could stimulate governmental accounting innovations. For the purposes of the model, innovations are defined as:

$$
\begin{aligned}
& \text {... conceptua[ly] not merely procedural changes of the accounting system to } \\
& \text { ensure the supply of comprehensive, reliable and meaningful financial } \\
& \text { information needed for accountability and sound financial management. } \\
& \text { (Lüder, 1994, p. 1) }
\end{aligned}
$$

Figure 1 illustrates the characteristics that create an unfavourable environment for the development of a governmental accounting system, as identified by Lüder (1992, p. 124). The opposite characteristics would create a favourable environment.

The final published version of Lüder's Model is being used in this study (Figure 2), which is summarized by Lüder (2002, p. 18):

\section{The financial management reform process model (...) consists of two clusters of contextual variables ('stimuli' and 'institutional arrangements'), three clusters of behavioural variables ('reform drivers', 'political reform promoters' and 'stakeholders') and two clusters of instrumental variables ('reform concept' and 'implementation strategy').}

In the illustration of the Lüder Model in Figure 2, 'feedback loops' are distinguished from 'lines of influence' and 'lines of impact'. The feedback loops represent the 'consequences of the real world', thus tying behaviour and attitudes of key actors in the innovation process to its results, taking into consideration the possibility of a multi-stage reform process. The addition of these loops are a very important contribution to the Model by Jaruga \& Nowak (1996), which changed the static model into a 'cybernetic learning system' (Chan et al., 1996, p. 9). 
FIGURE 1. UNFAVOURABLE CHARACTERISTICS ACCORDING TO LÜDER (1992)

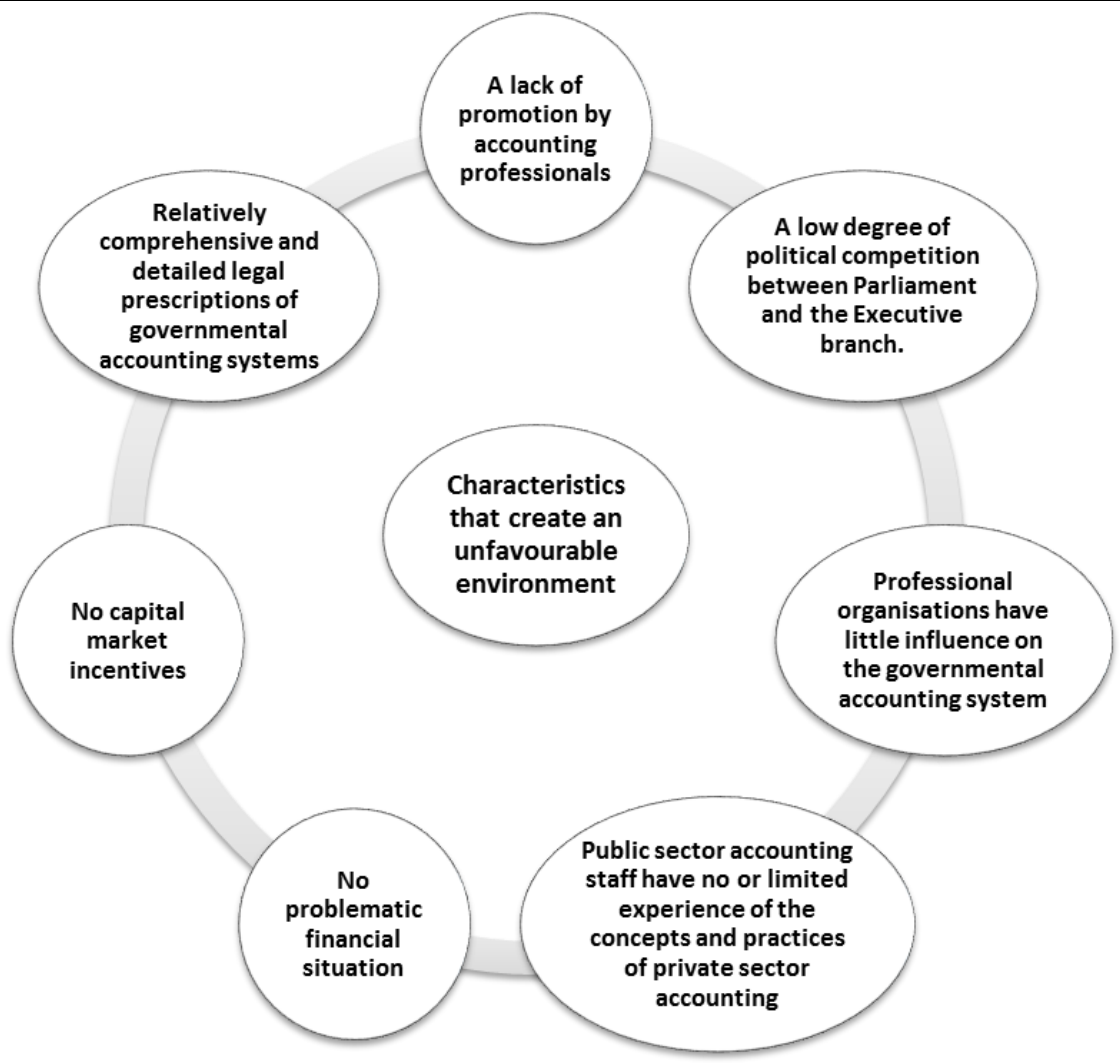

These feedback loops are considered necessary for the multi-stage process apparent in the Malta case, but they are missing from the simplified version of the 2002 Model as offered by Lüder (2013). The simplified version of the model is more elaborate on the actors, distinguishing between institutional opponents, information producers and information users. It also elaborates on the stimulus, distinguishing between problem-driven and doctrine-driven project initiations. The simplified version concludes the analysis of the reform with an examination of the new system in process. This is another reason why the summarized version is not chosen for the Maltese case study where the reform process is still in the preliminary stage, and, therefore, has no 'new system in process' to examine.

Christensen \& Yoshimi (2001) and Jorge et al., (2011) questioned the empirical validity of Lüder's Model due to speculative features of the complex multi-causal relationships between the variables in the framework. They are referring here to the lines of influence and the lines of impact connecting the various variables in the model. 
FIGURE 2. FINANCIAL MANAGEMENT REFORM PROCESS MODEL

(source: Lüder, 2002, p.18)

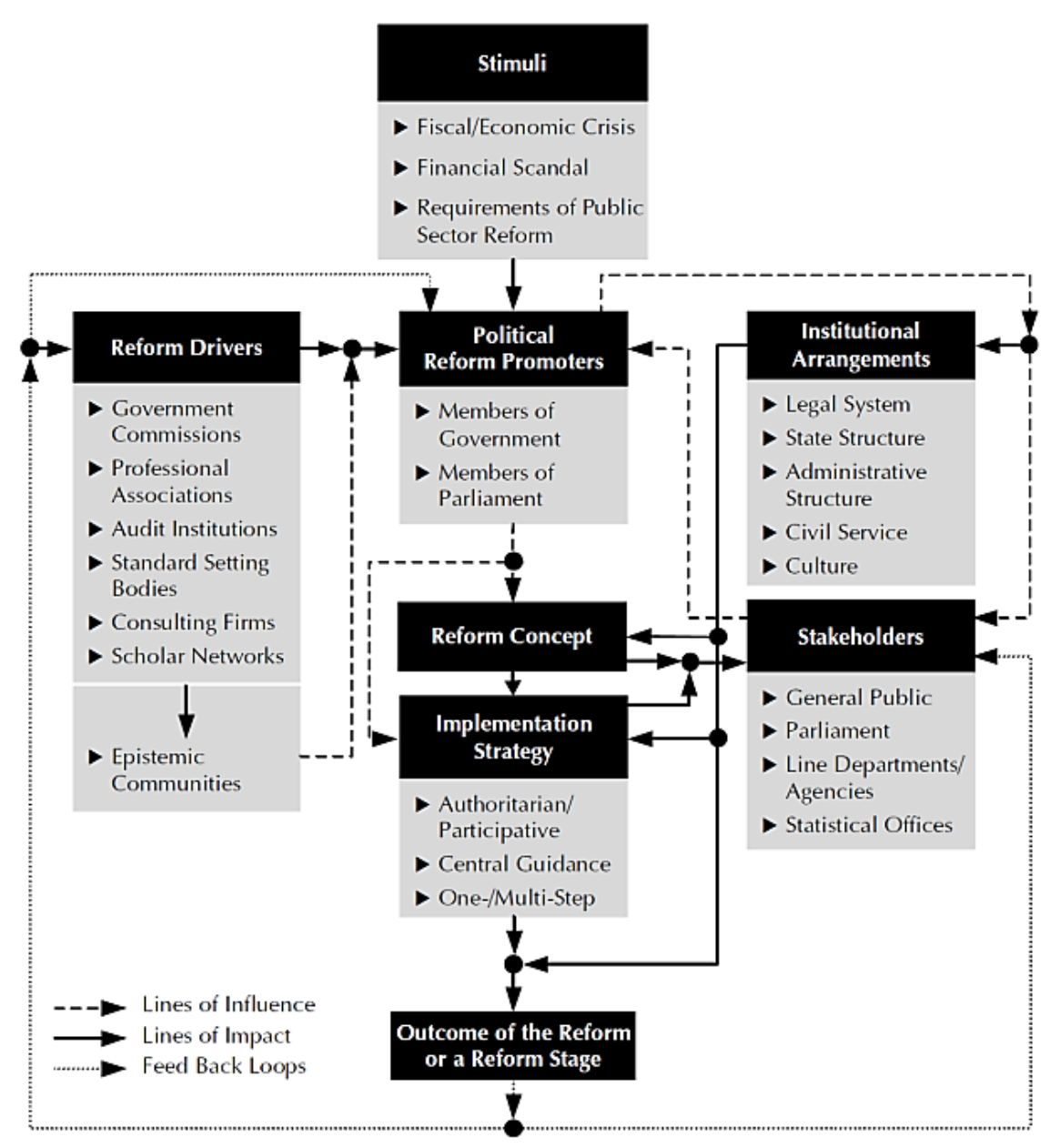

Lüder's Model started out as a contingency model based on contingency theory, placing more importance on the technical requirements, resource streams, information flows and influence relations. Lüder (1994) extended the original contingency theory approach to include variables of collective behaviour. The development of the model introduced more internal and external variables, at both micro and macro level; and the analysis of the cultural and institutional variables at macro level would attribute importance to symbols, cognitive systems, normative beliefs, and the source of such elements. Brunsson (1989) emphasised that a balance is required between the demand of the technical and institutional environments; Lüder's Model takes both types of environments into consideration. This study adds the institutional theoretical lens in the analysis in order to better understand the link between the various variables illustrated by the lines of influence and lines of impact. The result is a suggested integrated model. 


\subsection{Institutional theory and contingency theory}

According to contingency theory, an organization is the most effective when it adapts and fits itself to environmental factors. On the other hand, institutional theory focuses on the environmental factors and how these affect the organization.

Contingency theory proposes that performance outcomes of an organizational unit are a result of the fit between the unit's external context and internal arrangements (Van de Ven et al., 2013). The contingency theory approach advocates that there is no one best design for a management accounting information system, but it all depends upon situational factors, for example, the external environment and the internal organizational structure. The problem is that many of the contingent variables are rather abstract, and therefore are difficult to define and measure - for example, environmental uncertainty and organizational effectiveness.

Institutional theory focuses on the role of environmental forces in shaping and constraining organizations (Meyer \& Rowan, 1977; Powell \& DiMaggio, 1991; Scott, 2001). New practices are diffused and institutionalised as a result of external social and technical influences (Collier, 2001; Dillard et al., 2004; Lukka, 2007; Powell \& DiMaggio, 1991; Scott, 2001). Institutional theorists try to understand an organization's capacity to change by looking at how institutionalised requirements and values affect the choices available to it. Isomorphism and decoupling are the two main issues underlying this theoretical framework.

DiMaggio \& Powell (1983) defined isomorphism as a process through which organizations attempt to adopt similar socially accredited requirements, practices, and structures from their operating environment. Central to isomorphism is the notion of legitimacy, which enforces organizations to comply with external requirements, regardless of the appropriateness of these requirements for their specific setting (Ball \& Craig, 2010; Carpenter \& Feroz, 2001). Since organizational activities are strongly motivated by a behaviour that seeks legitimacy (Dillard et al., 2004), the search for legitimacy has often proved to be more important than rational decision-making processes (Connolly et al., 2009). Meyer \& Rowan (1977) argued that, by promoting legitimacy, institutional isomorphism increases the success and survival of organizations. DiMaggio \& Powell (1983) identified three mechanisms through which legitimated requirements and practices are transferred to organizations: (i) coercive - related to political pressure exerted on organizations by institutions upon which they are dependent; (ii) mimetic - this occurs when organizations, in situations of uncertainty, try to imitate other organizations that are perceived to be successful; and (iii) normative - occurring as a result of professionalization.

Decoupling refers to instances when accounting technologies are not absorbed in the actual practice of the organization, but remain a ceremonial tool or a product of social rationalisation in order for the organization to appear legitimate (Ball \& Craig, 2010; Oliver, 1991; Rahaman et al., 2004).

Legitimacy is the central concept of institutional theory. According to Scott (2001, p.59), legitimacy is 'a reflection of perceived consonance with relevant rules and laws, normative support, or alignment with cultural-cognitive frameworks'. In contingency theory, legitimacy links context to form (Van de Ven et al., 2013). Van de Ven et al., (2013) pointed out that institutional theory makes two important additions to contingency theory: firstly, to view ideas, values, and beliefs as important contextual constraints on organizations (Scott, 2001); and secondly, to revise the relationship between context, organizational form, and performance as usually defined (Meyer and Rowan, 1977).

Scott (1987, pp. 507-9) observed that separate application of the two theories provides an incomplete understanding of the different roles played by various practices. According to Scott (1987), contingency and institutional theories can be used together to better understand how organizational practices fulfil instrumental and symbolic roles. 


\subsection{An integrated model}

The contingency theory perspective suggests that an organization focuses on its technical activities and shapes its work processes to promote those activities while protecting them from disturbances in the external task environment (Gupta et al., 1994). The contrasting institutional perspective is that an organization gains legitimacy by conforming to external expectations of acceptable practice, and thus may ceremonially adopt elements of formal organizational structure to demonstrate the rationality of its operations to external constituents, rather than to control organizational members (DiMaggio \& Powell, 1983; Meyer \& Rowan, 1977). Gupta et al. (1994) pointed out that despite the apparent inconsistency between these two perspectives, theorists working within each recognise its interrelation with the other. Institutional and technical factors are dimensions along which environments vary, and both place pressures on organizations to which they must be responsive in order to survive (Powell, 1991, p. 186).

FIGURE 3. GOVERNMENTAL ACCOUNTING REFORM IN MALTA AT MACRO LEVEL
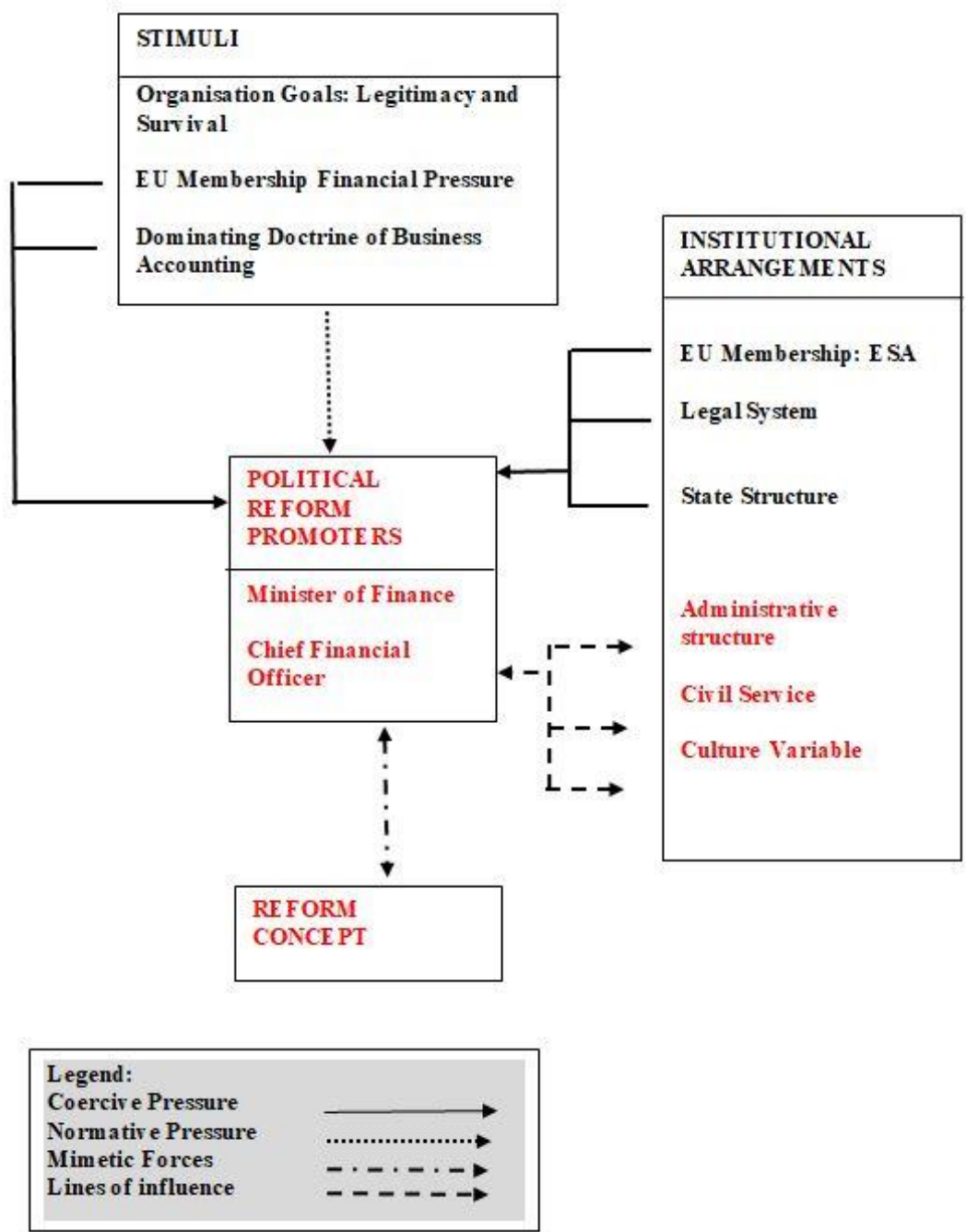
It is being suggested that Lüder's Model should be three dimensional, that is, the model should have two horizontal planes. The top plane focuses on the external environment, capturing the variables at macro (institutional) level and the forces they exert through the lens of institutional theory, as in Figure 3. In this plane, the lines of impact and lines of influence would refer to institutional forces - normative, mimetic or coercive in nature. The bottom plane shows the variables and lines of impact and lines of influence at micro (technical) level, as in Figure 4. In this plane, the connecting lines are at organizational level and of a technical nature. The holistic features of Lüder's model are retained as the two planes are interconnected: the common connecting variables between the two levels are the political reform promoters, the reform concept and part of the institutional arrangements.*

FiguRE 4. GoVERnMENTAL ACCOUNTING REFORM IN MALTA AT MICRO LEVEL

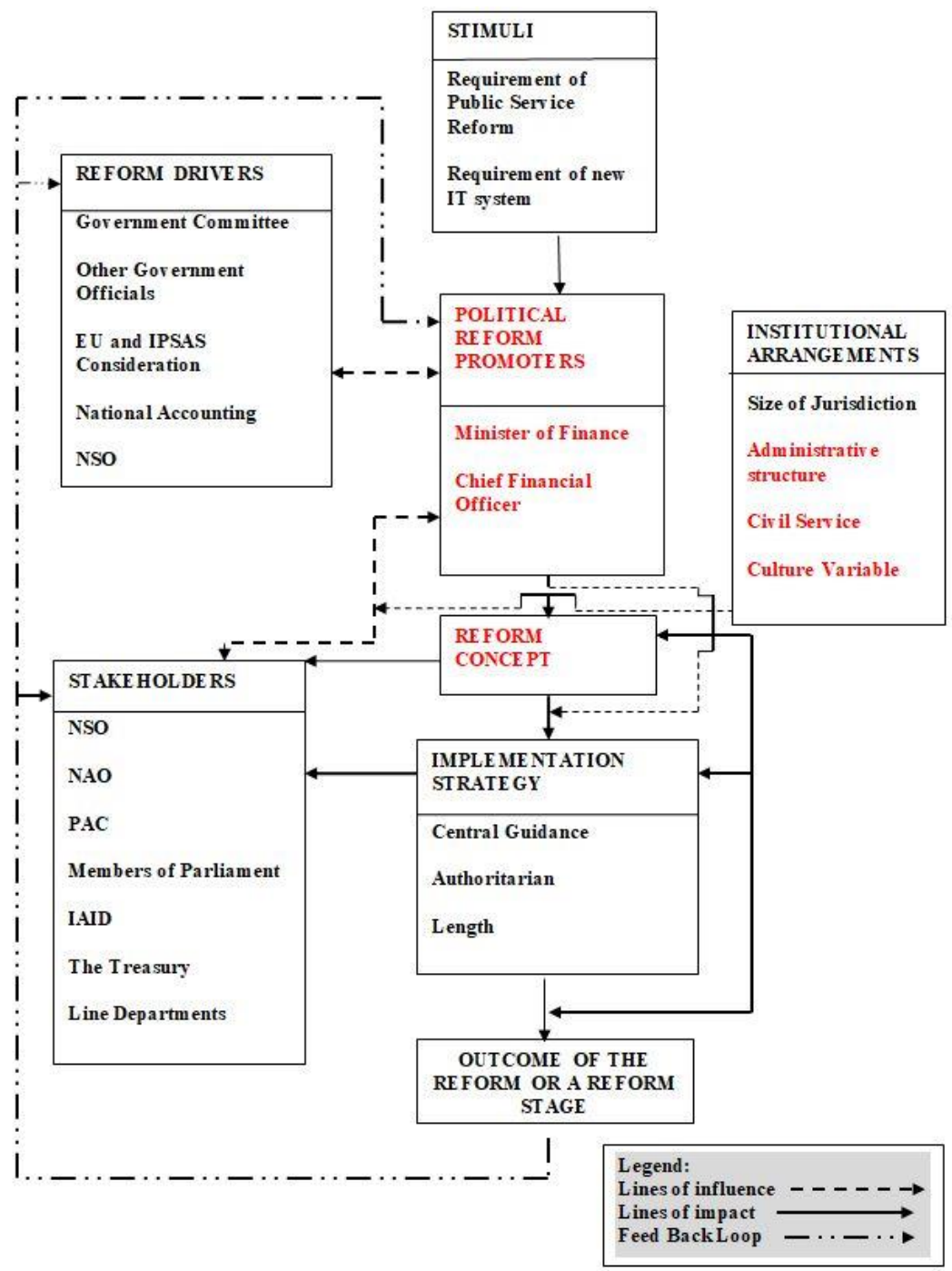

* The variables noted in each cluster illustrated in Figures 3 and 4 are as identified in this empirical study in the Maltese context. 
The rationale behind this suggestion is to attempt to differentiate between the extent of some forces (lines of impact and lines of influence) affecting the reform process. The political reform promoters are more exposed to pressures at macro level, and they also tend to act as a buffer for lower level actors from the effects of these institutional forces. The reform concept is included in this plane because of its symbolic inferences. The Administrative Structure and the Civil Service are also included in the macro level plane because the political reform promoters may carry out changes in these two variables not only for instrumental purposes but also to appear to comply with general expectations. The appointment of certain government officials who are inadequate or not interested in the reforms is one example. Scott (1992, pp. 211-2) refers to staff training as another example: 'Training staff indicates both instrumental competence and also ceremonial conformity to societal expectations that call for such credentials'.

\section{Research methodology}

A qualitative approach is taken for this longitudinal case study, using mixed methods of documentary research and interviewing. Triangulating documentary evidence with oral sources enhances the reliability of an account in recent history (Gidley, 2004) because it increases the validity of the findings due to corroborative evidence (Scapens, 2004).

\subsection{Documentary research}

The Malta Government website was gleaned to extract information regarding the structure, functions and operations of the Ministry of Finance. The Treasury Department's website refers to circulars and directives issued by the Treasury to the government departments, concerning the accounting reform. The minutes of two sessions of the Public Accounts Committee were located after a search on the Malta Government portal. In these sessions, held during 2009 and 2010, the accounting reform process was being described and discussed (PAC 2009, 2010). The Public Accounts Committee is the scrutinising arm of Parliament, and both the proceedings of meetings and minutes are available to the public.

Information regarding the proposed output from the government accounting system to be implemented in Malta is available from a public document issued by the Government of Malta in order to acquire a new 'Corporate Financial Management Solution' (CFMS) (MoF, 2014a). Various press releases by the Ministry of Finance, both before and after the issue of the tender, are also analysed in the context, together with a new law enacted in August 2014 (the Fiscal Responsibility Act) concerning financial responsibility in government finances.

Content analysis was used to analyse the documents. When using documents for research, Prior (2003) explained how important it is to keep in mind the dynamics involved in the relationships between production, consumption, and content. It is ideal to substantiate or otherwise, documentary findings, by interviewing people who were present at the time, and who were actually aware of the phenomena being investigated.

\subsection{Interviews}

The research participants were carefully identified and selected from the actors involved in the accounting reform process, in order to comprehensively cover the behavioural variable as identified by Lüder's Model (2002). The research participants chosen are described as political reform promoters, stakeholders and reform drivers (refer to Table 1). Lüder \& 
Jones' (2003) EuroCIGAR study was used as the basis for the format and content of the questionnaire used during the interviews.

A total of 28 interviews were carried out during the period October 2011 to September 2012. The interviews varied in length from one to two hours, and more than one interview session was necessary with some of the officials. The interview data was analysed using a form of thematic analysis, which was very theoretical-driven. 'Themes' are patterns in the data; the approach entails the identification of these patterns, which were then analysed and reported. The theory underlying Lüder's Model (2002) directed the analysis towards the identification of the contextual, behavioural and instrumental variables, and how these effectively interact to influence the environment making it conducive or otherwise to governmental accounting reforms.

In June 2014, Treasury officials involved in the issue of the tender for a new government accounting system were contacted for an interview, but they declined to participate so as not to compromise the tendering process, given that they are members on the adjudication board. The adjudication was still in process as at August 2016 and was finalised in August 2017.

\section{TABLE 1. THE RESEARCH PARTICIPANTS}

\begin{tabular}{|c|c|c|}
\hline $\begin{array}{l}\text { Political Reform Promoters (1): } \\
\text { Politicians and/or government } \\
\text { officials who initiate a reform and } \\
\text { have power to enforce it }\end{array}$ & $\begin{array}{l}\text { Stakeholders (21): } \\
\text { depending on their discretionary } \\
\text { powers, these actors may affect the } \\
\text { reform process }\end{array}$ & $\begin{array}{l}\text { Reform Drivers (6): } \\
\text { also known as 'epistemic } \\
\text { communities', these actors may } \\
\text { influence the decisions of political } \\
\text { actors }\end{array}$ \\
\hline $\begin{array}{l}\text { - the Permanent Secretary at the } \\
\text { Ministry of Finance (top civil } \\
\text { service employee) }\end{array}$ & $\begin{array}{l}\text { - Two Parliamentary members } \\
\text { (members of the Public Accounts } \\
\text { Committee) } \\
\text { - The Accountant General } \\
\text { - The Director for Government } \\
\text { Accounting } \\
\text { - An Accountant at the Treasury } \\
\text { - The Director General for Internal } \\
\text { Auditing and Investigations } \\
\text { - The Deputy and Assistant } \\
\text { Auditor General } \\
\text { - The Director for Financial Policy } \\
\text { Development and Analysis } \\
\text { - The Budget Office } \\
\text { - The Director General for } \\
\text { Strategy and Operations Support } \\
\text { - The Manager at MITA } \\
\text { responsible for the new IT } \\
\text { system } \\
\text { - Nine Directors for Corporate } \\
\text { Services (heading the } \\
\text { accounting functions of } \\
\text { Ministries) }\end{array}$ & $\begin{array}{l}\text { - The Technical Officer of the } \\
\text { Malta Institute of Accountants } \\
\text { - A MITA official on the } \\
\text { Departmental Accounting } \\
\text { System } \\
\text { - The first chairman of the Accrual } \\
\text { Accounting Task Force (retired) } \\
\text { - A partner at the private audit firm } \\
\text { that was responsible for writing } \\
\text { accounting standards specifically } \\
\text { for the Maltese government } \\
\text { (prior to the decision to adopt } \\
\text { IPSAS) } \\
\text { - A Member of the Government } \\
\text { Finance Statistics Committee } \\
\text { from the National Statistics } \\
\text { Office } \\
\text { - The ex-Director of the Budget } \\
\text { Office }\end{array}$ \\
\hline
\end{tabular}




\subsection{Limitations}

The main limitation of this study is the subjectivity involved in certain interpretations of the interview data. As a result, the values of both the interviewees and the interviewer are unavoidably reflected in this study.

Another limitation is that the classification of research participants into stakeholders, reform drivers and political reform promoters, is not as straightforward as it seems in theory. Perhaps the behavioural cluster of variables needs to be better explained, or perhaps it is difficult to capture these distinctive theoretical meanings in reality.

\section{The first three chapters of the never-ending story according to Lüder's Model}

The governmental accounting reform process in Malta started in 1999, with a Treasury circular that announced the implementation of accrual accounting in the Central Government. The reform was to be led by the Accrual Accounting Task Force within the Ministry of Finance. According to this circular and interview responses, the decision appears to have been taken with the intention of improving economy, efficiency and effectiveness of government operations, with the adoption of the business accounting model.

The accounting reform process can be divided into three phases, namely: from 1999 to 2004; from 2004 to 2013; and from 2013 to date. Therefore, the years 2004 and 2013 are two important turning points in this never-ending story.

Two things happened in 2004: EU membership and a new Finance Minister. EU membership is now part of the institutional arrangement (a contextual variable). The new Finance Minister represents a change in a behavioural variable - a change in the political reform promoter. It appears that a change in the combination of these two variables reduced the conduciveness of the environment towards accounting reform. It also appears to have affected the reform concept itself, in the sense that the reason why the implementation of a full accrual accounting system is deemed desirable changed to satisfying EU reporting requirements.

The general election of March 2013 resulted in a change in administration. An economist was appointed as Minister of Finance. His predecessors were both accountancy professionals. He retained the same Permanent Secretary, whose background is statistics. The Permanent Secretary is the chief financial advisor of the government, and he is identified as the main political reform promoter in this study. This change in the contextual and behavioural variables, can be said to have triggered the third phase of governmental accounting reform in Malta.

The first task of the Minister of Finance appointed in 2013 was to enhance the functioning of the National Statistics Office (NSO) with the aim of improving the statistical data collected, in particular, the data that is reported to the EU. According to the Minister of Finance, the NSO plays a vital role 'in providing the necessary information the Government requires to guide the country towards stability and greater economic growth' (MoF, 2013b).

The Minister then targeted the accrual accounting reform process. The Ministry of Finance appointed the Chartered Institute of Public Accountancy and Finance (CIPFA) to carry out a scoping study and identify the best way forward for the accounting reform. The CIPFA organised seminars on IPSAS for government officials, and presented the results of its study in October 2013 (MoF, 2013c). The factors holding back the reform 
that were identified in the CIPFA study are: a general lack of accountancy knowledge and proficiency in the civil service; lack of communication between the actors involved in the reform process; the requirement of a new legislation and IT support system (Camilleri, 2014). The Minister agreed that the reform should proceed based on IPSAS, since it is anticipated that there will be no major differences from the proposed EPSAS, given that IPSAS are indisputably the ideal reference for the development of EPSAS (MoF, 2013c). The Minister perceives the accounting reform as achievable and that it would be beneficial for society in general (MoF, 2013c). He described it as a long-term project, and the underlying aim is to produce more reliable data for government finance statistics (MoF, 2013a).

On 10th January 2014, the Maltese Government issued a tender to acquire a new accounting system. The closing date of the public tender was extended three times, with the final closing date being end of May 2014. The tender requires the proposed output to conform with IPSAS and with the Public Finance Management Act, which legislation has not yet been finalised. A draft of the law does not appear to be publicly available as yet. As to the financing of the project, the budgetary estimates for 2014 did not allocate funds for the acquisition of this project (MoF, 2013d). The tender document states that the project may be eligible for EU funds. Up to 2012, government authorities had claimed that EU funding was not available for this type of administrative expenditure. Now it appears that the EU may consider to partly finance such an investment, which could be understandable in view of the EC's support for the implementation of accrual accounting systems by governments of member states (Eurostat, 2013).

\subsection{Contextual variables}

\subsubsection{Stimuli}

Government accounting reform in Malta appears to have been instigated as part of an overall reform of the Public Service undertaken in 1990. The proposed reform initiated by the 1999 Treasury circular was managerial-driven, and the ultimate aim was that accounting will be used as a management tool across the board. The dominating doctrine of superiority of business accounting was acting as a stimulus.

The implementation was ready to proceed, but during 2004, the new Minister of Finance was faced with financial pressures that accompany EU membership in order to satisfy the Maastricht criteria. Since EU regulations do not require a member state to have an accrual accounting system, the Maltese authorities concentrated their limited resources on meeting the accrual reporting required by the European System of Regional and National Accounts (ESA). Once these requirements were being met, with a patched-up system of cash and accrual data (known as modified cash basis), the drive for implementing a full accrual accounting system stopped:

And we started; we had a certain drive ... When we arrived to the state
that the Commission was accepting our data and confirmed that our
methodology was correct - at that stage, we sort of reached a plateau, and
the impetus stopped. So the drive appeared to be more in order to satisfy
EU reporting requirements. I cannot say that this is so $100 \%$, but the fact
remains that once we reached this stage, we died. (Interview:
Stakeholder)

The only fiscal stress that Malta experiences emanates from EU financial requirements and the efforts done in order to avoid an excessive deficit procedure. The dominating doctrine of the superiority of accrual accounting is acting as an indirect stimulus through the EU Commission. However, this financial pressure acted as a deterrent in the case of Malta, rather than a stimulus. The accrual accounting reform was not abandoned because the apparent motions were still there: the committees and the preparatory work by the 
Treasury were ongoing. But by 2012, the process had stalled, while the administration waited for the EU to prescribe what needs to be done:

\section{But since the EU decision is still pending, we are waiting for the EU to issue the direction first... Now we have to see what the EU outcome will be. (Interview: Stakeholder)}

Lüder \& Jones (2003) identified the requirement to change the IT system as a stimulus. This has become an urgent issue for the Maltese Government because the current system is outdated and there is the risk of lack of technical support in order to maintain it. The issue of the public tender in January 2014 for the government to acquire both the IT hardware and software for a CFMS (MoF, 2014a) may be interpreted as the first tangible step taken indicating that the accounting reform process may have experienced a 'spark'. But the need for updating the IT system is not the actual stimulus that triggered the new thrust in the third phase of the reform - the trigger was the change in administration in 2013, and the new Minister of Finance, fresh from the opposition bench.

\subsubsection{Institutional arrangements}

Malta is a unitary state with a one-chamber parliament. An unbalanced division of power favouring the Executive makes the state structure conducive to government-induced reforms; but on the other hand, Parliament has no power to induce reforms. Since both sides of Parliament appear to support accrual accounting reform, perhaps the state structure is irrelevant in the case of Malta. The change in administration in 2013 did not result in a change in policy towards government accounting. It was the change in the behavioural variable that affected the reform process in 2013.

It is normally expected that the implementation of a new accounting system is easier and less expensive in a smaller jurisdiction (Lüder, 1992, p. 118). Regardless of the size of the country, its administration requires a staple quantity of human resources in order to deal with all the functions. Even if human resources are kept to a minimum, the fixed element would still reflect a high percentage in a relatively small population. Expertise is limited to the same small cluster of officials that is involved in all aspects of the reform, and specialization is barely possible. The small size of the jurisdiction then acts as a constraint as limited human resources can only be absorbed on prioritized issues, while not-soimportant issues, like the back-end accounting system, are placed on a 'waiting list'. One stakeholder described his responsibilities at the Ministry of Finance as "you name it all and there is no limit ... and amongst many things, there is this accrual accounting". As at May 2012, the same stakeholder confirmed the accrual accounting reform is not considered as "top urgent" and that "there are no deadlines at this stage".

The size of the jurisdiction is important when considering the administrative structure as a contextual variable. Administration is highly centralized, which is desirable to ensure consistency and uniformity of accounting reform across the central government. But this means that responsibilities and pressures are concentrated on a small group of people. On the other hand, when some of the responsibilities of the Accrual Accounting Task Force were delegated to other directors within the Ministry of Finance, it appears that the process stalled further. This happened when the political reform promoter changed in 2004, so it could have been the intention of this behavioural variable to have this negative effect. It also appears that lack of communication within the administrative structure, leading to undefined roles and conflict, may be acting as a negative factor. Following the CIPFA recommendations, the IPSAS Committee within the Ministry of Finance should be more focused on its work of analysing the reporting standards and preparing a manual for departmental use. The problem is that the IPSAS Committee is made up of existing public service employees. The demands of their role on the committee are over and above their present duties. 
Due to competitive remuneration offered by the private sector, the government fails to attract accounting professionals. The public service does not promote exciting job positions, and even the education system tends to concentrate on private sector opportunities. A deficit also exists in the legal framework which does not provide for particular professional training for accountants to practice in the public sector. Lack of accounting knowledge and skills is, therefore, pervasive in the civil service. However, developments during the second phase, for example, the restructuring of the Treasury, together with increased specific training opportunities that became available, may have reversed this trend to a more favourable situation.

The tender document issued in 2014 refers to a Public Finance Management Act - a law that does not exist. The Public Finance Management Act should have replaced the existing Financial Administration and Audit Act (1962) that prescribes government accounting, reporting and financial procedures. This law currently in force does not refer to accrual accounting methodology. It may be a case of putting the cart before the horse, but it does not make the financial legislation totally unfavourable to changes in the accounting system because the existing legislation empowers the Minister of Finance to issue accounting standards through a legal notice that does not require Parliamentary approval. Although the financial legislation is prescriptive as to accounting procedure and report content, new rules in the form of circulars from the Ministry/Treasury are regularly issued. After 2004, however, the number of circulars concerning accrual accounting trickled to nothing. As the Maltese authorities were awaiting instructions from the EU in order to proceed, especially with regards to government accounting standards, the legal system effectively became a negative factor during the second phase.

In the third phase, the priorities of the current Minister of Finance are evident in the new piece of legislation enacted in August 2014. The Fiscal Responsibility Act (2014), is all about budgeting, accountability and performance targets - which targets are those specifically laid out in EU Council Regulations concerning the excessive deficit procedure, budgetary surveillance and coordination. It describes the Government Annual Report as basically a budgetary execution report, comparing actual results with the fiscal targets being the Maastricht criteria. It does not mention the Treasury and the proposed accrual accounting system or the ensuing financial reports based on IPSAS. It focuses on EU reporting requirements and the Maastricht criteria; thus reinforcing the important role of the NSO in decision making and adherence with the ESA. Like other EU member states, the ESA is engrained in the legislation. The ESA exerts strong coercive pressure in Malta and has affected the reform.

The culture variable incorporates social, political and administrative tendencies. The traditional paternal system of government plays a large role in the culture variable. There appears to be a high level of responsiveness to the demands of the general public, but the democratic structure is still in the process of modernization especially with regards to increased transparency in political and administrative processes. A certain degree of risk aversion is demonstrated in that the same political party tends to govern for more than one electoral period; the reluctance to change the financial legislation; and the cautiousness shown towards accounting reform because of the uncertainty about the impact on financial reporting especially with regards to the EU. The small size of the country does promote individualistic competition, but it all depends on the personal characteristic of the official. When the accounting reform started, the two main actors were rather individualist, and the reforms were managerial-driven. Then the actors changed, collectivism became more pronounced, with actions depending a lot more on committee decisions, and the accounting reform became more accountability-driven. This tendency appears to have slowed down the reform process.

The institutional arrangements include other implementation barriers, for example, funding. Funding could be acting as a negative factor because its source is still not clear. The Financial Estimates for 2015 and 2016 (MoF, 2014b; 2015) do not include sufficient 
allocation of funds for the acquisition of the new IT system.* The tender document suggests that EU part-financing of the project may be considered under the rules of the Operational Programmes for Malta Cohesion Policy 2014-2020. The actual funding of the project does not appear planned but gives the impression of being a shot in the dark. These factors are not very encouraging and give a rather careless impression of how such an important investment decision has been taken. In August 2017, when the award of the contract for the new accounting system was publicly announced, it was stated that the investment is eligible for EU funding.

\subsection{Behavioural variables}

\subsubsection{Political Reform Promoters}

The Members of Parliament in Malta are not political reform promoters because the Parliament is not strong enough to enforce reforms against the resistance of the Executive. The Minister of Finance is a member of the Executive and has the power to begin and complete the reform. The Minister who had started the reform in 1999 upheld the importance of the accounting system as a management tool. Together with the support of the main reform driver, being the Chairman of the Accrual Accounting Task Force, the Minister championed the reform and infected the actors with enthusiasm. In 2004, the groundwork was ready to begin implementation, but then the Minister changed due to internal party politics. The new Minister was an accountant like his predecessor, but came from a different professional background, and he was also faced with a different contextual environment due to increased financial pressures emanating from $\mathrm{EU}$ membership. A combination of these factors resulted in the accounting reform to slowly wane.

The new Minister of 2004 appointed a new Permanent Secretary at the Ministry of Finance. The Permanent Secretary is the Chief Financial Advisor of the government, and even though not a political appointment, he can be considered as a political reform promoter since all the other actors in the reform follow his instructions. On the retirement of the Chairman of the Accrual Accounting Task Force, the Permanent Secretary took over the accounting reform; but it was not the main item on his agenda and he cannot be described as a 'champion'. His background in statistics and economics did not help either because he tended to emphasize the importance of national accounting, and he effectively influenced the reform concept to change in that direction:

\section{The original raison d'etre was to stop the manipulation that is possible with a cash based system, and thus have a complete reporting system. With the change in our statistics, that raison d'être died. (Interview: Political reform promoter)}

The position of the current Finance Minister elected in 2013 is also worthy to consider. When sitting on the bench of the Opposition, this economist was vociferous about the importance of an accrual-based accounting system. During the budget discussions preceding the general election, he had publicly stated that the government is treating the Maltese like second-class citizens because while it is using the accrual basis for EU statistical reporting, the government is producing financial reports for local consumption on a cash-based system. He compared the cash-based reports with those prepared by a club, claiming that the reports lacked in accountability and transparency.

\footnotetext{
* The funds allocated for the acquisition of the new IT system are $€ 1,000,000$ in 2016 (€400,000 in 2015) (MoF, 2015, p. 223; 2014b, p. 247); while $€ 55,000$ ( $€ 50,000$ in 2015) have been allocated as revenue expenditure to the Treasury for IPSAS implementation (MoF, 2015, p. 196; 2014b, p.219).
} 
After making such criticism, the economist had to show that he is doing something about it once he was elected. The signals have been given in the form of a study as to IPSAS implementation and the issue of the tender. The underlying objective, however, still appears to be macro-level reporting because the Minister has stated that this system will help to improve the data used for statistical reporting to the EU. The apparent hastiness in the issue of the tender may be the result of the need of the Minister to show that he is taking tangible action. Another possible reason may be that it is considered as an opportune time to make such investment in view of the possibility of obtaining financial assistance from the EU.

The Minister for Finance has the power to initiate and complete the reform process. The Minister in the third phase is an economist. The two preceding Ministers were accountants. However, this makes no difference in expectations between the second and third phases of the reform. If anything, the economist shows a more overwhelming thrust towards statistics, macro level reporting and ESA. As a new player on the scene, the Minister is driven by the need to legitimise his position and actions.

\subsubsection{Reform drivers}

The behaviour of reform drivers influences the political reform promoters, and thus all the reform process. Also referred to as 'epistemic communities', including experts who share the same views on the main features of the reform, and thus their influence on the reform process is strengthened (Laughlin \& Pallot, 1998).

The Accrual Accounting Task Force was set up in 1999 in order to implement accrual accounting throughout the Central Government of Malta. The Task Force appeared very effective in the first phase. Its first Chairman 'owned' the project; he enjoyed the full support of the Minister of Finance, and thus was an effective reform driver. However, when the political reform promoter changed in 2004, the responsibilities of the committee were scattered across the Ministry of Finance. Eventually, the Chairman retired, and the project was taken over by the Permanent Secretary who had to delegate some of the responsibilities. This was done by involving directors who already had enough on their plate. During the second phase, the reform drivers in the Task Force were not exercising any influence on the political reform promoter, but awaited instructions from him in order to act. They did not demonstrate the individualistic characteristics like their predecessor.

At the beginning of the reform process, the Malta Institute of Accountants did show some enthusiasm by setting up a Public Sector Committee. But this interest waned over time, and the professional body did not attempt to make governmental accounting reform a political issue or to somehow try to influence political decision makers. As is typical of countries in Continental Europe (Lüder, 1992, p. 114), professional interest in public sector accounting appears weak in Malta.

There are no accounting standard setting bodies in Malta.* The attempt to formulate accounting standards for the Maltese Government was abandoned in favour of IPSAS in 2011, since the latter provide more credibility (Jones \& Caruana, 2016). Having said this, however, no particular interest was shown towards pronouncements issued by the IFAC and the IPSASB. These accounting standard setting bodies have only managed to influence the reform process, through the auspices of the EU. In fact, in 2012, when the EU Commission decided to undertake the study on the feasibility of IPSAS for member states, the work of the IPSAS Committee (a sub-committee of the Task Force) stopped to await the outcome of this study. The IFAC and the IPSASB could, therefore, be considered as reform drivers at EU level, but it is then EU membership that acts as a reform driver for government accounting reform in Malta. The actual existence and

* The Private Sector is required to comply with the IFRS framework. This has been a compulsory requirement since 1995, according to the Companies Act. 
availability of IPSAS had no effect on the reform process during the first two phases. Their adoption in 2011 could have boosted the accounting reform, but the involvement of the EU lead to further justified procrastination.

The decision to adopt IPSAS was taken in 2011, and the underlying objective was for the government to appear credible and legitimate (Jones \& Caruana, 2016). Two years later, the CIPFA was appointed to carry out a study in order to legitimize this decision, given that the CIPFA openly supports IPSAS adoption by governments. Thus the CIPFA appears in the third phase as a reform driver, and it is actively assisting the Treasury for training requirements. As a result, the work of the IPSAS Committee at the Treasury was re-ignited during 2014; and the assistance of the Malta Institute of Accountants was sought in 2016, which once again set up a Public Sector Committee for the purpose. It is too early to assess the contribution of this nascent committee to the reform process.

EU membership brought to the fore the importance of adhering to ESA requirements due to the important objectives that are tied with statistical reports, which are a product of national accounting. It is not surprising that Malta's limited human resources concentrate on this issue, albeit to the detriment of the accrual accounting reform, resulting in the ESA being a very effective reform driver in its own way. Heald \& Georgiou (2011) describe national accounting as an epistemic community since it is external to government accounting but still exercises influence on the political reform promoters. In the Maltese context, the influence of the ESA appears to be very high and coercive in nature: the ESA is in fact a legal requirement, part of the institutional arrangement, and is fundamental to meeting the Maastricht criteria: 'ES $A$ is the framework that is discussed and is the framework that we have to work with' (Interview: Stakeholder).

This makes the NSO a major reform driver since its expertise in ESA requirements is sought and relied upon by the political reform promoter. This is contrary to the situation of the National Audit Office and the Public Accounts Committee - two bodies that could be considered as reform drivers but are not influential.

\subsubsection{Stakeholders}

Due to its involvement in the decision-making process, the NSO has been included with the reform drivers, but it is also a stakeholder since it does have an interest in a more informative accounting system that is more in line with the accrual system used for the National Accounts. The government uses a cash-based system for its accounting and the NSO is responsible for converting this data in accordance with ESA requirements. At present, the NSO places a lot of reliance on the work of the Treasury in collecting accrual data from the government departments. The overall influence of the NSO may not be in line with the original reform concept and may have contributed to the redefining of the reform objectives, with more emphasis on the requirements of ESA.

On the other hand, the National Audit Office and the Public Accounts Committee are stakeholders who are not so influential on the political reform promoters. Their views appear to be more in line with accounting reform that is managerial-driven rather than accountability-driven. The same applies for the Internal Audit Directorate, even though the latter appears to be more informed about how the reform concept has changed and appears willing to be flexible and open to any kind of change that results in an improvement in the accounting system.

The Maltese Members of Parliament are the representatives of the general public. Parliamentary members are stakeholders who give the appearance of upholding an accounting system that would improve transparency and accountability but perhaps are not so well-informed about what changes are required in order to achieve this. The majority of parliamentary members do not have a financial background and includes mostly medical doctors and lawyers. Subsequently, they are easily persuaded by the 
opinions of the political reform promoters. One result of this is that, during the second phase of the reform, the majority of parliamentary members were convinced that an accrual accounting system was in use because reporting to the EU was on an accrual basis.

The Treasury is a very important stakeholder that has persisted in its work in the accounting reform. Due to its reluctance to initiate reforms itself, however, it cannot be described as a reform driver. Even its potential influence as a stakeholder is dampened due to the position that it is taking with regards to decision-making, and in its persistence to regard itself as 'the executive arm' of the Ministry of Finance rather than the decision taker.

The line departments appear to be supporting the accrual basis because they are expecting more autonomy as a result since they assume that accrual accounting would mean the end of the annuality principle. Perhaps the line departments would be satisfied with a new IT system, which is more user friendly, together with some free hand as to the carry forward of unused funds. This appears to be their actual expectation as to how an accrual accounting system would affect them positively.

None of the stakeholders have discretionary powers to affect the reform, since the Ministry of Finance maintains total control over the process. The stakeholders do not appear to be offering any kind of resistance because the political reform promoter has led the key stakeholders to a neutral position. This is a successful indicator for the reform process (Lüder, 2002), but according to the 'revised' reform concept.

\subsection{Instrumental variables}

\subsubsection{Reform concept}

When the accounting reform started in 1999, the idea was to implement a full accrual accounting system that will be used as a financial management tool across the board, in addition to the cash based system. Accrual-based budgeting was part of the plan, and a dual reporting system was envisaged. The work carried out by the Chairman of the Accrual Accounting Task Force during the first phase of the reform was in line with this reform concept, which was managerial-driven.

In the second phase of the reform, the actors appeared uncertain about the actual utility of an accrual-based budget, even at departmental level. And the Political reform promoter was rather skeptical about the innovativeness of the accounting reform overall:

\section{When eventually we will have a more sophisticated system, I believe that it will not produce results that are very different from what we have today. (Interview: Political reform promoter)}

A stakeholder confirmed that the actual output from the accounting reform was a concept that was still work in progress:

\section{The fact that the present Minister has declared the same things as the previous Minister, confirms that the idea is still on - the end result may be different but the reform is still ongoing. (Interview: Stakeholder)}

The reform concept is under the direct influence of the political reform promoter acting on the advice and opinions of reform drivers. The main reform drivers in the case of Malta appear to be the EU and National Accounting. The reform concept appears to have reacted to this feedback, and became tantamount to providing more reliable data for national accounts and statistical reports. If this is now the reform concept, then one could argue that the reform concept did not only change but was even being achieved. "Satisfying EU reporting requirements could be perceived as the target for using accrual accounting" (Interview: Stakeholder), and since "the EU is happy this way, and we are not infringing our obligations, it would be a waste of resources should we be scrupulous" (Interview: Reform Driver). Therefore, the 
government accounting reform would have been actually successfully completed during the second phase and no further changes were required. But the reform process continued.

It should be quite straightforward to identify the reform concept in the third phase because it should be specified in the tender document. However, the output from the CFMS according to the tender is a bit shady because it is required to take into consideration the requirements of a non-existent financial legislation and undefined reporting standards. Even the background to the project contains unclear statements. For example,
... [The CIPFA scoping study] is an initiative to identify the gaps between the current state of its accounting standards and that of the IPS AS-based European Financial framework ... [which] requirements shall form part of this tender... In line with other EU member states, Government aims to introduce International Public Sector Accounting Standards (IPSAS) in the coming years along with other EU financial regulations which are becoming a mandatory requirement for governments to implement. $\quad$ (MoF, 2014a, p. 75)

This implies that the government is anticipating that the EU will issue government accounting standards that will be mandatory across EU member states; or is it a statement to justify its actions?

It has always been intended to retain the current cash-based accounting system and implement accrual accounting as an add-on. In fact,

\section{The proposed Solution is to address the current cash-based and new accrual accounting models and other business requirements. Hence, to bring this into fruition, the proposed Solution needs to support both models concurrently. $\quad(\mathrm{MoF}, 2014 \mathrm{a}, \mathrm{p} .75)$}

The same applies for budgeting, with one of the objectives of the CFMS being 'to create coherent financial and budgetary Systems that conform both to cash and accrual based methodologies' (MoF, 2014a, p. 79).

As also suggested by the Political reform promoter in the interview, the proposed solution is not expected to produce any reporting that is spectacularly different from what is currently being produced by the modified cash based system. ${ }^{*}$ The tender describes the current system as a 'prototype of what Government is expecting' (MoF, 2014a, p. 75). After describing the current model, the tender document then states that:

\section{This model shall be replaced by the new Corporate Financial Management Solution to be procured and implemented, in accordance to accrual-based International Public Sector Accounting Standards (IPSAS), supporting local legislation - the Public Finance Management Act [?] and EU Directives, Regulations and Standards. (MoF, 2014a, p. 76)}

The new system is required to cater for other types of international reporting which apply various standards, including 'EU standards in development'. The contractor, therefore, is being required to be flexible enough to respond to future standard requirements, like EPSAS, for example. But no questions have been raised about these requirements in the clarification phase, further confirming that no big changes are expected from EPSAS.

It is a pity that the cost and management accounting module is not being given due importance; an essential management tool should be part of the core system requirements and not considered as something optional. This indicates that there is no intention to use

\footnotetext{
* Modified cash based system refers to cash based reporting plus accrual data collected from government departments and ministries on specific templates provided by the Treasury.
} 
the proposed accounting system as a financial management tool across the board. After all, in the third phase of the reform, the most important purpose attached to the reform is that it provides more reliable data for macro statistical reporting. This was stated by the Minister of Finance (MoF, 2013a; 2013c).

\subsubsection{Implementation strategy}

The reform concept changed during the second phase due to the extended length of the implementation period, and in the meantime, even the contextual and behavioural variables changed. The process was experiencing reform fatigue, or perhaps it was never intended for innovations to be rapidly implemented, after all,

Accrual accounting is like Dr Jekyll and Mr Hyde. We want it and we don't want it. (Interview: Reform driver)

There was never a stimulus. The reform was just a good idea at

the back of everyone's mind. If there was a stimulus, we would have long arrived to our destination. There was no stimulus because the perception of the politicians, at least the feel I get from the meetings of the Public Accounts Committee, with all the files and questions: that although they pay lip service to accrual accounting as providing more accountability and transparency, because these are the buzzwords, they do not really understand accrual accounting. And to a certain extent, they do understand the budget. So I don't think that there is some hot fervour to change things. (Interview: Stakeholder)

The process has always been authoritarian and centrally guided, which should be more conducive to a successful reform. However, central guidance appeared lacking during the second phase: the intention was there, but the change in the administrative structure and the behavioural variable had reduced the quality of this guidance. The Accrual Accounting Task Force existed on paper, but no work was being done. The same applied for the IPSAS Committee, which held ad hoc meetings, and was waiting expectantly for EU directions in order to proceed. A multi-step approach towards implementation was being planned, but a new accounting system was required in order to initiate the implementation and this decision was still pending:

The tender has not been issued. Whether it's expensive or not, whether for other motives, I don't know. What I know is that I completed the project. I delivered. Somehow the system is not here yet. (Interview: Stakeholder)

I think that the last thing they want on their plate is to do this accrual accounting. Even the meetings that were held lately, it's like they are done very quickly, just to record that a meeting has been held, and it appears that there is no drive. (Interview: Reform Driver)

In the third phase, the details of the implementation strategy are described in the tender document (MoF, 2014a:80-92) as multi-step with pilot testing; centrally guided with minimal discretion allowed; and systematic training throughout the process. These factors should have a positive effect on the reform process, provided that the IPSAS Committee functions properly. The implementation strategy is also outlined in CIPFA's scoping study, but this is not a guarantee of the Minister of Finance's actions. The CIPFA plan proposes an implementation period of six years (Camilleri, 2014), which is described as long by Lüder \& Jones (2003). If one takes into consideration that work on the foundations started in 1999, the total implementation period is not very encouraging. 


\section{Conclusions from Lüder's model}

The set up for the government accounting reform in Malta is all there - in fact, it has been there for more than 15 years. For Brunsson (1989), Christensen \& Lægreid (1998) and Pollitt (2000), there are differences between 'reform talk', 'reform decisions', 'actual implementation of reforms', and 'results' (Torres \& Pina, 2004, p. 450). The reform process has been described in three phases. These phases were not planned, but happened because of changes in contingent variables - both external and internal. Characteristics that create an unfavourable environment for the development of a governmental accounting system, as identified by Lüder (1992, p. 124) (refer to Figure 2), are all present in the Maltese context.

TABLE 2. LÜDER'S MODEL IN MALTA - INTERFERENCE OF ENVIRONMENTAL CONDITIONS TO GOVERNMENTAL ACCOUNTING INNOVATIONS

\begin{tabular}{|c|c|c|c|}
\hline & $1999-2004$ & $2004-2013$ & $2013-$ \\
\hline CRITERIA & \multicolumn{3}{|c|}{ CONDUCIVENESS TO INNOVATION } \\
\hline \multicolumn{4}{|c|}{ CONTEXTUAL VARIABLES } \\
\hline \multicolumn{4}{|l|}{ STIMULI: } \\
\hline \multicolumn{4}{|l|}{ - Requirements of overall reform of whole Public } \\
\hline Administration & + & $=$ & $=$ \\
\hline \multicolumn{4}{|l|}{ - Dominating doctrine of superiority of business } \\
\hline accounting & + & $+1=$ & $+1=$ \\
\hline - Financial Pressures (from EU membership) & $=/+$ & $+/-$ & $+/-$ \\
\hline - Economic crisis & $=$ & $=$ & $=$ \\
\hline \multirow[t]{2}{*}{ - New IT System requirement } & $=/+$ & + & + \\
\hline & + & $=$ & $=$ \\
\hline \multicolumn{4}{|l|}{ INSTITUTIONAL ARRANGEMENTS: } \\
\hline - Legal system & $-/+$ & $+/-$ & $+/-$ \\
\hline - State structure & $=$ & $=$ & $=$ \\
\hline - Size of Jurisdiction & $+/-$ & - & - \\
\hline - Administrative structure & $+/-$ & $+/-$ & $+/-$ \\
\hline - Civil service & $+/-$ & $-/+$ & $-/+$ \\
\hline - Culture & $-/+$ & $+/-$ & $+/-$ \\
\hline \multirow[t]{2}{*}{ - Funding } & - & - & - \\
\hline & - & - & - \\
\hline \multicolumn{4}{|c|}{ BEHAVIOURAL VARIABLES } \\
\hline \multicolumn{4}{|l|}{ REFORM DRIVERS: } \\
\hline - Government Commissions & + & $+1=$ & $=/+$ \\
\hline - Professional Associations & $+1=$ & $=$ & $-/+$ \\
\hline - International Standard Setting Bodies & $=$ & $=/+$ & $=/+$ \\
\hline - EU & $-/+$ & $+/-$ & $+/-$ \\
\hline \multirow[t]{2}{*}{ - National Accounting and statistical office } & $=$ & $+/-$ & $+/-$ \\
\hline & + & - & + \\
\hline \multicolumn{4}{|l|}{ POLITICAL REFORM PROMOTERS: } \\
\hline - Members of Parliament & $=$ & $=$ & $=$ \\
\hline \multirow[t]{2}{*}{ - Members of Government } & + & $+/-$ & $+/-$ \\
\hline & + & - & - \\
\hline \multicolumn{4}{|l|}{ STAKEHOLDERS: } \\
\hline - Statistical Office & $=$ & $+/-$ & $+/-$ \\
\hline - Audit Institutions & $+1=$ & $=$ & $=$ \\
\hline - Parliament & $=$ & $=$ & $=$ \\
\hline - General Public & $=$ & $=$ & $=$ \\
\hline - Treasury & + & $+1=$ & $=/+$ \\
\hline - Line departments & $+/-$ & $-/+$ & $-1+$ \\
\hline
\end{tabular}




\section{TABLE 2. LÜDER'S MODEL IN MALTA - INTERFERENCE OF ENVIRONMENTAL CONDITIONS TO GOVERNMENTAL ACCOUNTING INNOVATIONS}

\begin{tabular}{|c|c|c|c|}
\hline & $1999-2004$ & $2004-2013$ & $2013-$ \\
\hline \multirow[t]{2}{*}{ CRITERIA } & \multicolumn{3}{|c|}{ CONDUCIVENESS TO INNOVATION } \\
\hline & $=$ & $=$ & $=$ \\
\hline \multicolumn{4}{|c|}{ INSTRUMENTAL VARIABLES } \\
\hline REFORM CONCEPT & + & $+1=$ & $=$ \\
\hline \multicolumn{4}{|l|}{ IMPLEMENTATION STRATEGY: } \\
\hline - Training & $-/+$ & $-1+$ & $-1+$ \\
\hline - Central guidance & + & $+/-$ & $-1+$ \\
\hline - Authoritarian & + & $+/-$ & $+/-$ \\
\hline - Multi-step & + & $+/-$ & $+/-$ \\
\hline \multirow{2}{*}{ - Implementation period } & $+/-$ & - & - \\
\hline & + & - & - \\
\hline OVERALL ASSESSMENT & Favourable + & Negative - & Negative - \\
\hline
\end{tabular}

In the first phase from 1999 to 2004, the reform was managerial-driven, with the aims being a more efficient, effective and economic public management, and to have an accounting system that provides helpful tools for decision-making at micro entity level. The accounting reform was part of a comprehensive administrative reform, and there was no apparent fiscal stress. Using Lüder's Model (2002), it can be concluded that the variables present in the first phase of the process had created a favourable environment to change. The overall positive effects of the behavioural and instrumental variables, together with the stimuli, could overcome the negative impact of the institutional arrangements (refer to Table 2).

The reform changed in 2004 to one that was more accountability-driven, with more importance being placed on reporting at macro level. The environment of the second phase of the process (from 2004 to 2012) appeared to be less conducive to change. The two main factors causing this change were EU membership (contextual variable) and a new Finance Minister accompanied by a Permanent Secretary who was a statistician by profession (behavioural variable). A change in the combination of these two variables appeared to reduce the conduciveness of the environment towards accounting reform and affected the reform concept itself. In fact, towards the end of 2012, the accounting reform appeared to have stalled, with the government authorities waiting for further direction from the EU. The decision taken in 2011 to fully adopt the IPSAS did not appear to have had any effect on the process, and was merely a ceremonial decision that presented legitimating perceptions towards the whole government apparatus. The only positive stimulus in the second phase was the need to change the outdated IT accounting system. The institutional arrangements remained negative. The negative impact of the reform drivers and the political reform promoters had neutralised the position of the stakeholders and the reform concept itself (Table 2). The length and quality of the implementation strategy were also having a negative effect on conduciveness to innovations.

In the third phase (2013 to date), the stimulus for the new accounting system is not powerful enough to neutralise the institutional arrangements, given that the underlying financial legislation is not supporting proper implementation of accrual accounting. The contextual variables are thus having an overall negative effect on the reform process. The overall effect of the behavioural variables is not important. The positive effect of the reform driver in the form of the CIPFA, is neutralised by the perceived 'utility' of the governmental accounting system by the political reform promoters. The instrumental variables are also having a negative effect. The length of the implementation has resulted in a change of the reform concept. While it is taken for granted that an accrual accounting 
system is the desired end result, the perceived utility does not fit with innovation that the Lüder's Model proposes (Lüder, 1994, p. 1).

The analysis concludes that the change in Administration in 2013 does not seem to have affected the environment of the reform process in the third phase, which remains negative (Table 2). The only difference from phase two is that the actors are not blatantly waiting for further directions from the EU, but are going through the motions of implementation. The CIPFA study and the issue of the tender appear to be legitimating strategies for political accountability. The real changes may be different from what is being publicly stated because the reform concept remains better reporting at macro level. This is how the political reform promoters are interpreting EU pressure; and thus 'translating' this pressure onto lower levels of the organization as the reform concept.

Contrary to Pallot's (1995) conclusion that smaller countries follow a managerial-driven approach to implement governmental accounting reform, it appears that in Malta, the second and third phases are more accountability-driven. The first phase appears to conform to Pallot's suggestion, but then the direction changed after 2004 due to the macro context becoming more powerful. The approach came to resemble more of that of larger countries.

\section{A more holistic understanding of the reform through the Integrated model}

Applying the suggested integrated model for the Malta case, primary focus is on the Political Reform Promoters who are more susceptible to institutional pressures from the external environment (that is, at macro level) because of the need to appear legitimate in the decisions that they take. The political reform promoters then sieve these forces through the organization (that is, at micro level) in terms of more technical directions. In this way, even the organization gains legitimacy by conforming (or appearing to conform) to external expectations of acceptable practice. It is true that the underlying stimulus for overall changes in the government structure that started in the 1990s was the desire to apply for EU membership and to be prepared for this with a more modern government apparatus. So one can say that EU membership permeated the wider changes in the Public Service. But the effect of this on the Political Reform Promoters at institutional level, and their subsequent 'translation' onto the technical level varied over time, as shown in Table 3.

\section{TABLE 3. AN OUTLINE INTEGRATED MODEL FOR THE MALTA CASE}

\begin{tabular}{|c|c|c|}
\hline $\begin{array}{l}\text { REFORM } \\
\text { PHASE }\end{array}$ & INSTITUTIONAL (MACRO) LEVEL & TECHNICAL (MICRO) LEVEL \\
\hline $1999-2004$ & $\begin{array}{l}\text { The Political Reform Promoter and the main reform } \\
\text { driver were both accountants by profession. Both the } \\
\text { Minister for Finance and the official responsible for the } \\
\text { reform appreciated the potential utility of an accrual } \\
\text { accounting system as a financial management tool } \\
\text { across the board. The influence was of a normative } \\
\text { nature, because the dominating doctrine of accrual } \\
\text { accounting as practiced in the private sector was part } \\
\text { of their professional training. }\end{array}$ & $\begin{array}{l}\text { The proposed changes were managerial-driven. } \\
\text { The instructions given in the form of a circular } \\
\text { outlined the implementation of a full accrual } \\
\text { accounting system to be used for decision making } \\
\text { at all levels of government. } \\
\text { Adequate preparations for implementation were } \\
\text { being taken. } \\
\text { It was like a big explosion ... there was a huge } \\
\text { drive. (Interview: Stakeholder) }\end{array}$ \\
\hline & & $\begin{array}{l}\text { The lines of influence and lines of impact at this } \\
\text { level created a positive environment that supported }\end{array}$ \\
\hline
\end{tabular}




\section{TABLE 3. AN OUTLINE INTEGRATED MODEL FOR THE MALTA CASE}

\begin{tabular}{|c|c|}
\hline $\begin{array}{l}\text { REFORM } \\
\text { PHASE }\end{array}$ & INSTITUTIONAL (MACRO) LEVEL \\
\hline $2004-2013$ & $\begin{array}{l}\text { The Political Reform Promoters changed in 2004. The } \\
\text { Minister of Finance was an auditor and the official } \\
\text { responsible for the reform a statistician. The new } \\
\text { context of EU membership and the requirements for } \\
\text { Euro adoption and maintenance exerted coercive } \\
\text { pressure on their perception of the utility of the } \\
\text { accounting system. } \\
\text { Decoupling is observed at this point as the reform } \\
\text { concept changed to one that supported reporting to } \\
\text { the EU. The decision to adopt IPSAS was taken in } \\
\text { 2011, but accounting technologies were not absorbed } \\
\text { in actual practice. The accounting system remained } \\
\text { cash-based and budget-oriented, but was patched up } \\
\text { with a system of accrual data collection in order to } \\
\text { satisfy EU reporting requirements according to ESA. } \\
\text { The decision to adopt the IPSAS was a ceremonial } \\
\text { decision that presented legitimating perceptions } \\
\text { towards the government apparatus. } \\
\text { The accounting reform stalled but maintained the } \\
\text { appearance of being ongoing: }\end{array}$ \\
\hline
\end{tabular}

Putting up appearances as if you are installing it everywhere, and no one has its leadership, or its leadership is not so important compared with other things. (Interview: Stakeholder)

The task force and all the other committees were not dismantled, but in effect nothing was being done as these waited for instructions from the political reform promoters. Thus the process became ceremonial giving the impression that the accounting system is being changed to imitate those of other jurisdictions perceived to be more successful.

This mimetic pressure was exacerbated by an aura of uncertainty that permeated the process due to lack of accounting knowledge by public service officials; fear of how a full-blown accounting system shall impact EU reporting; EU interest in government accounting systems, IPSAS and the lack of IPSAS knowledge; and the EC's plans to develop the EPSAS, which are still an unknown quantity. It can be concluded that the ceremonial process of change was maintained only due to the external pressure exerted by the EU for member states to implement accrual accounting systems.

In appearance, it seems that the project will be executed - and in fact this 'appearance' can be delayed forever. (Interview: Reform Driver).

2013 to date The Minister of Finance changed once again in 2013, to an economist. The other Political Reform Promoter remained the same statistician. The effect of this change strengthened the effect of the coercive nature change to an accrual accounting system.

The process of change became accountabilitydriven.

Reporting to the EU became the de facto outcome. Since this was somehow being achieved, there was a confused 'understanding' that accrual accounting had actually been implemented.

The lines of influence and lines of impact at this level overall created an environment that stalled the process of change to an accrual accounting system.

Accrual accounting is important to give a holistic picture. How far have we arrived to date? I would say that we are there with the adjustments being done by the NSO. (Interview: Reform Driver)

The annual deficit is accrual-based. The monthly and quarterly data collected is accrual-based. The entities use an accrual accounting system. And still there are people who think that the government is operating a cash-based system ... Government accounting is currently cash-based but reporting is not. ... All our reporting is accrual-based, even to the EU .... Even the National Accounts issued by the NSO are accrual-based. (Interview:

Stakeholder)

The accrual accounting reform is not considered as top urgent ... there are no deadlines at this stage. (Interview: Stakeholder)

The accounting reform at central level has not stopped. It has been successfully suffocated and placed on the back burner. (Interview: Reform Driver)

The process of change remains accountabilitydriven.

The lines of influence and lines of impact at this level may create a semblance of change to an 


\section{TABLE 3. AN OUTLINE INTEGRATED MODEL FOR THE MALTA CASE}

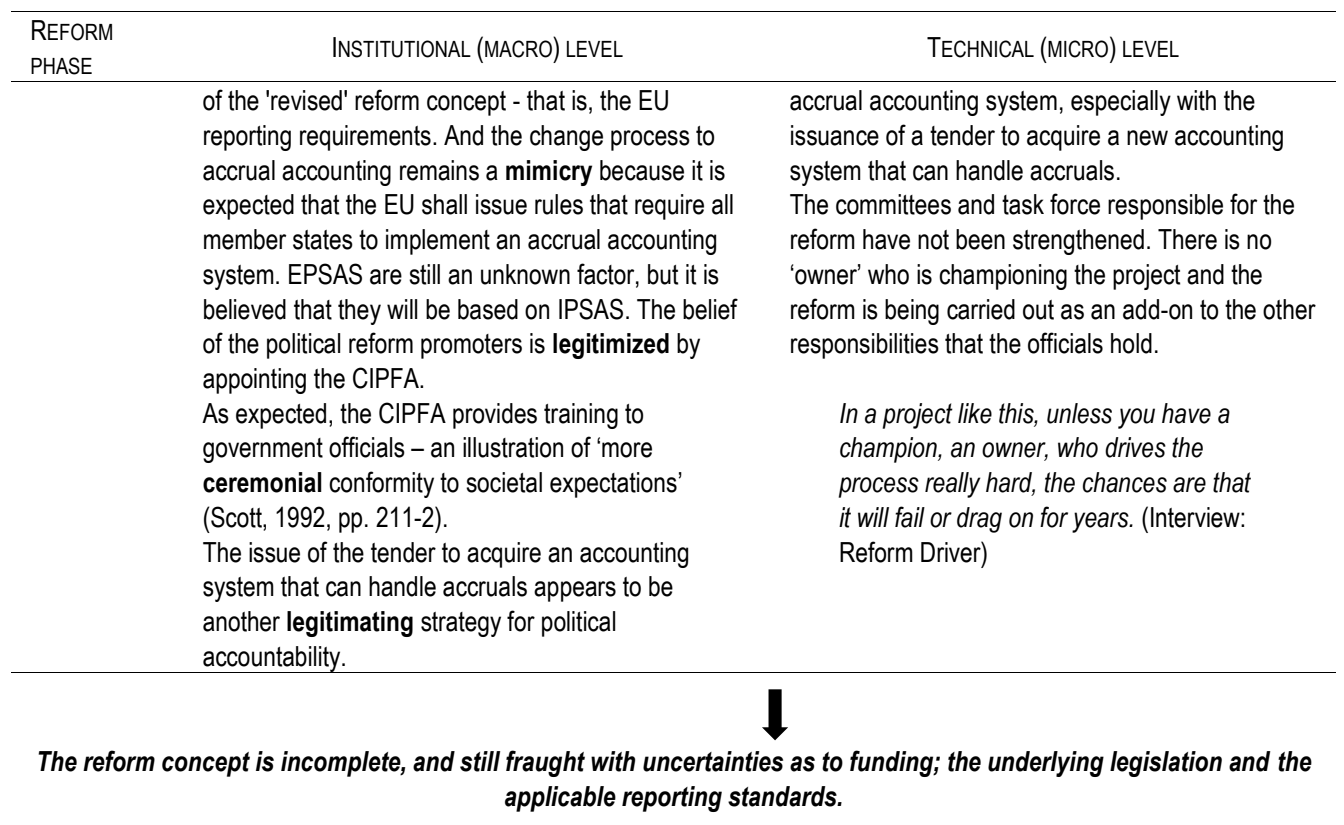

Christensen \& Parker (2010, p. 251) deemed it useful to focus on organized groups behind change in order to use neo-institutional theory in understanding diffusion. In the Malta case, these organized groups appear missing. CIPFA is a reform driver, but it is being used as a legitimating tool - its involvement in the process is convenient rather than instrumental, because the decision to proceed with IPSAS had already been taken. As pointed out by Macintosh (1985), accounting information systems can end up as rationalization machines that seek to justify and legitimize actions that have already been decided. The findings in this case study are more consistent with those of Carpenter \& Feroz (2001, p. 567) that, amongst other influences, idea transference is 'profoundly influenced by the personal beliefs of key organizational decision-makers'. This study highlights that these personal beliefs are in turn influenced by the external environment, and the need to appear legitimate and rational in the macro sphere.

\section{Conclusion}

The Malta case study is important because it explains why a government would develop a new accounting system before deciding on the broader conceptual design features behind that new system. The fact that the government does not have a formal accounting system that is considered as 'modern' by the external environment makes it vulnerable to claims of negligence. As suggested by institutional theory, accounting systems may be adopted ceremonially in order to convince the environment of the legitimacy and rationality of the organization's activities. As a result, the reality of accruals-based accounting systems in actual use could prove to be quite different from the rhetoric of government about accruals accounting in advance of implementation (Connolly \& Hyndman, 2006, p. 288). 
The Maltese administration changed in 2013, bringing in a new behavioural variable in the accounting reform, namely a new Minister for Finance. This appears to have fueled the government accounting reform into action, with the issue of the tender for a new CFMS being the most tangible step taken towards implementation of a new accounting system for the central government. While this augurs well for changes to actually happen, it is doubtful whether the investment would actually proceed should it not qualify for EU funding. The issue of the tender prior to changes in the financial legislation makes the whole process rather opaque; a fact that should worry interested contractors. Uncertainty about the applicable financial reporting standards surround the process; the system is required to adhere to standards that are still being discussed, namely EPSAS. Relying on the European Commission's opinion that IPSAS provide an indisputable reference point for the development of EPSAS, the proposed system is required to comply with IPSAS and IFRS. The findings indicate that the Maltese authorities expect EPSAS to be mandatory for all EU member states, but do not expect EPSAS to differ much from IPSAS. The CIPFA was included in order to legitimise this position. All this uncertainty may, perhaps, not really matter since the underlying aim is to produce more reliable data for government finance statistics - this is the thrust felt from the EC and the Maltese authorities respond accordingly in order to appear to be doing the right thing.

There is no argument that the issue of the tender for the acquisition of the new accounting system is a tangible step forward in the Maltese government's accounting reform, but perhaps the timing is wrong, and even the main stimulus of it all. The underlying uncertainties may result in a waste of resources and effort. Perhaps it would have made more sense for the government to wait for further instructions from the EU before proceeding with this important step. The investment required in the new system could then be better utilised to produce reporting that focuses on what really matters for the government and produce information that is actually used for decision making. The application of Lüder's Model in the third phase of this accounting reform reveals that there is actually not much difference from the second phase and the accounting reform remains illusory because the target is still macro-reporting. The new accounting system is perceived as a way how to achieve more reliable financial statistics, and thus the environment cannot be described as conducive to innovations.

The theoretical contribution of the paper is the development of the integrated model that explains reform processes by combining institutional and contingency theories. Based on contingency theory, Lüder's model includes a mix of external and internal variables. Using the institutional theoretical lens while applying Lüder's Model in the Maltese context suggests that the model can better explain what is happening by expanding the model three dimensionally. A distinction is made between forces and variables at macro (external) and micro (entity) levels. The integrated model suggests to first focus on the external environment, as these forces at macro level affect the political reform promoter (the main decision maker), who then sieves these through to micro and organizational level. The proposed amendment of the Lüder's Model to two connected planes is emphasising the balance between the technical and institutional environments (Brunsson, 1989); and it is also illustrating how myth theories often focus on phenomena at macro level and relate these to effects and implications on an organizational level (Gupta et al., 1994).

This proposal aims at extending the discussion surrounding the criticism of Lüder's Model in not clarifying the extent and direction of the lines of influence and the lines of impact (Christensen \& Yoshimi, 2001; Jorge et al., 2011). The integrated model proposes that in order to better understand a governmental accounting reform process, it is important to first examine the external environment and identify the institutional pressures being exerted at macro level, as being experienced by the political reform promoters. For example, for EU member states, the EU context would definitely be an influential factor. Similarly, jurisdictions that are reliant on funding from institutional lenders would also be susceptible to pressures from these external variables. The integrated model makes it crucial to examine the macro situation first, before proceeding to examine what is actually 
happening at micro level. The latter would be dependent on the personal beliefs of the political reform promoters; and how these are affected by and responding to external macro forces.

It is important to point out that the magnitude of the effect of the macro level forces on the reform process at micro level cannot be generalised. Even though countries may be subject to the same types and levels of institutional pressures - coercive; normative; mimetic - the effects of pressures at macro level on the particular jurisdiction would depend on national political and economic factors. Perhaps larger jurisdictions may be less vulnerable to external pressures. It would be interesting for future research to test the integrated model in larger contexts that are perhaps less centralized than that covered in this case study.

\section{References}

Abernethy, M., \& Chua, W. (1996). A field study of control system redesign: the impact of institutional processes on strategic choice. Contemporary Accounting Research, 13(2), 569-606.

Ansari, S. L., \& Euske K. J. (1987). Rational, rationalizing, and reifying uses of accounting data in organizations. Accounting, Organizations and Society, 12(6), 549-570.

Ball, A., \& Craig, R., (2010). Using neo-institutionalism to advance social and environmental accounting? Critical Perspectives on Accounting, 21(4), 283-293.

Brunsson, N. (1989). The organization of hypocrisy. Talk, decisions and actions in organizations. Wiley, Chichester.

Burns, J. (2000). The dynamics of accounting change: inter-play between new practices, routines, institutions, power and politics. Accounting, Auditing \& Accountability Journal, 13(5), 566-596.

Camilleri, N. (2014). The adoption and implementation of internationally recognized public accounting standards in Malta. The Accountant, (Winter 2014), 36-40.

Carruthers, B. G. (1995). Accounting, ambiguity and the new institutionalism. Accounting, Organizations and Society, 20(4), 313-328.

Carpenter, V. L., \& Feroz, E. H. (1992). GAAP as a symbol of legitimacy: New York State's decision to adopt generally accepted accounting principles for external financial reporting. Accounting, Organizations and Society, 17(7), 613-643.

Carpenter, V. L., \& Feroz, E. H. (2001). Institutional theory and accounting rule choice: An analysis of four US state governments' decisions to adopt generally accepted accounting principles. Accounting, Organizations and Society, 26(7-8), 565-96.

Chalmers, K., \& Godfrey, J. M. (2004). Reputation costs: the impetus for voluntary derivative financial instrument reporting. Accounting, Organizations and Society, 29(2), 95-125.

Chan, J. L. (1994). Accounting and financial management reform in the United States Government: an application of professor Lüder's contingency model. In Buschor, E., Schedler, K. (Eds.), Perspectives on Performance Measurement and Public Sector Accounting (pp. 17-41) Berne: Paul Haupt Publishers.

Chan J. L., Jones, R. H., \& Lüder, K. G. (1996). Modelling governmental accounting innovations. In Chan, J.L., Jones, R.H. \& Lüder, K.G. (Eds.), Research in governmental and nomprofit accounting (Vol.9, pp. 1-19) Connecticut: JAI.

Christensen, M. (2003). Without 'reinventing the wheel': business accounting applied to the public sector. Australian Accounting Review. 13(2), 22-27.

Christensen, M., \& Parker, L. (2010). Using ideas to advance professions: public sector accrual accounting. Financial Accountability \& Management, 26(3), 246-66. 
Christensen, M., \& Yoshimi, H. (2001). A comparison of Japanese and Australian second tier government performance reporting. In Jones, R.H. (Ed.), Public sector accounting (Volume 4, pp. 47-64). London: Sage.

Christensen, T., \& Lægreid, P. (1998). Public administration in a democratic context - a review of Norwegian research. In Brunsson, N., Olsen, J.P. (Eds.), Organizing Organizations. Bergen: Fagbokforlaget.

Chung, L. H., Gibbons, P. T., \& Schoch, H. P. (2000). The influence of subsidiary context and head office strategic management style on control of MNCs: the experience in Australia. Accounting, Auditing \& Accountability Journal, 13(5), 647-666.

Collier, P. (2001). The power of accounting: A field study of local financial management in a police force. Management Accounting Research, 12(4), 465-486.

Connolly, C., \& Hyndman, N. (2006). The actual implementation of accruals accounting: Caveats from a case within the UK public sector. Accounting, Auditing \& Accountability Journal, 19(2), 272-290.

Connolly, C., Reeves, E., \& Wall, A. (2009). Isomorphism: an explanation for the popularity of public-private partnerships? The Irish Accounting Review, 16(1), 1-19.

Covaleski, M. A., \& Dirsmith, M. W. (1988). An institutional perspective on the rise, social transformation, and fall of a university budget category. Administrative Science Quarterly, 33(4), 562-587.

Covaleski, M. A., \& Dirsmith, M. W. (1991). The management of legitimacy and politics in public sector administration. Journal of Accounting and Public Policy, 10(2), 135-156.

Covaleski, M. A., Dirsmith, M. W., \& Michelman, J.E. (1993). An institutional theory perspective on the DRG framework, case-mix accounting systems and health-care organizations. Accounting, Organizations and Society, 18(1), 65-80.

Dillard, J., Rigsby, J., \& Goodman, C. (2004). The making and remaking of organizational context. Accounting, Auditing \& Accountability Journal, 17(4), 506-542.

DiMaggio, P. J., \& Powell, W. W. (1983). The iron cage revisited: institutional isomorphism and collective rationality in organizational fields. American Sociological Review, 48(2), 147-160.

Dirsmith, M. W., Heian, J. B., \& Covaleski, M. A. (1997). Structure and agency in an institutionalized setting: the application and social transformation of control in the Big Six. Accounting, Organizations and Society, 22(1), 1-27.

Eurostat. (2013). Towards implementing harmonised public sector accounting standards in Member States: The suitability of IPS AS for the Member States. 6 March, COM (2013)114.

Fogarty, T. J. (1996). The imagery and reality of peer review in the U.S.: insights from institutional theory. Accounting, Organizations and Society, 21(2/3), 243-267.

Fogarty, T. J., \& Rogers, R.K. (2005). Financial analysts' reports: an extended institutional theory evaluation. Accounting, Organizations and Society, 30(4), 331-356.

Geiger, D. R., \& Ittner, C. D. (1996). The influence of funding source and legislative requirements on government cost accounting practices. Accounting, Organizations and Society, 21(6), 549567.

Gidley, B. (2004). Doing historical and archival research. In Seale, C. (Ed.), Researching society and culture, $2^{\text {nd }}$ Edition (pp. 249-264). London: Sage.

Godfrey, A. D., Devlin, P. J., \& Merrouche, C. (1996). Governmental accounting in Kenya, Tanzania, and Uganda. In Chan, J.L., Jones, R.H., Lüder, K. (Eds.), Research in governmental and nonprofit Accounting (Vol. 9, pp.193-208) Greenwich: JAI.

Godfrey, A.D., Devlin, P.J., \& Merrouche, C. (2001). A diffusion-contingency model for government accounting innovations. In Bac, A. (Ed.), International comparative issues in government accounting (pp. 279-296) Boston: Kluwer Academic Publishers.

Granlund, M., \& Lukka, K. (1998). It's a small world of management accounting practices. Journal of Management Accounting Research, 10, 153-179. 
Greenwood, R., \& Hinings, C. R. (1996). Understanding radical organizational change: Bringing together the old and new institutionalism. Academy of Management Journal, 21(4), 1022-1054.

Gupta, P. P., Dirsmith, M. W. \& Fogarty, T. J. (1994). Coordination and control in a government agency: contingency and institutional theory perspectives on GAO audits. Administrative Science Quarterly, 39, 264-284.

Haldma, T. (2006). Uneven ways of improvement of local government accounting: evidence from Estonian municipalities. In Lande, E., Scheid, J.C. (Eds.) Accounting reform in the public sector: mimicry, fad or necessity (pp. 163-176) Paris: Experts Comptables Media.

Heald, D. \& Georgiou, G. (2011). The macro-fiscal role of the U.K. whole of government account. Abacus, 47(4), 446-476.

Hood, C. (1995). The 'new public management' in the 1980s: Variations on a theme. Accounting, Organizations and Society, 20(2/3), 93-109.

Hussain, M. M., \& Hoque, Z. (2002). Understanding non-financial performance measurement practices in Japanese banks: a new institutional sociology perspective. Accounting, Auditing \& Accountability Journal. 15(2), 162-183.

Jaruga, A., \& Nowak, W.A. (1996). Toward a General Model of Public Sector Accounting Innovations. In Chan, J.L., Jones, R.H., Lüder, K. (Eds.), Research in Governmental and Nonprofit Accounting (Vol. 9 p. 21-31) Greenwich: JAI.

Jones, R., \& Caruana, J. (2016). Governmental accounting in Malta towards IPSAS within the context of the European Union. International Review of Administrative Sciences. 82(4), 745-762.

Jorge, S. (2003). Local government accounting in Portugal in comparative international perspective. PhD Thesis. University of Birmingham, Birmingham.

Jorge, S. (2005). The reform of governmental accounting in Portugal: an application of Lüder's contingency model. In Bourmistrov. A., Mellemvik, F. (Eds.), International trends and experiences in government accounting (pp. 28-48) Oslo: Cappelen Akademisk Forlag.

Jorge, S., Caperchione, E., \& Jones, R. (2011). Comparative International Governmental Accounting Research (CIGAR): bridging researching and networking. In Jones, R. H. (Ed.), Public Sector Accounting (Vol. 4, pp. ix-xxiv), London: Sage.

Lapsley, I., \& Pallot, J. (2000). Accounting, management and organizational change: a comparative study of local government. Management Accounting Research. 11(2), 213-229.

Laughlin, R., \& Pallot, J. (1998). Trends, patterns and influencing factors: some reflections. In Olson, O., Guthrie, J., Humphrey, C. (Eds.), Global warning: debating international developments in new public financial management. Oslo: Cappelan Akademisk Forlag.

Lüder, K. (1992). A contingency model of governmental accounting innovations in the Politicaladministrative environment. In Chan, J.L., Patton, J.M. (Eds.), Research in governmental and nomprofit accounting (Vol. 7 pp. 99-127) Greenwich: JAI.

Lüder, K. (1994). The contingency model reconsidered: experiences from Italy, Japan and Spain, in: Buschor, E., Schedler, K. (Eds.), Perspectives on Performance Measurement and Public Sector Accounting (pp. 1-15) Haupt: Berne et al.

Lüder, K. (2002). Research in comparative governmental accounting over the last decade: achievements and problems. In Montesinos, V., Vela, J.M. (Eds.), Innovations in Governmental Accounting (pp. 1-21) The Netherlands: Kluwer Academic Publishers.

Lüder, K. (2013). Accrual accounting and budgeting in government - a history of the Hessian new administrative management (NVS) project. Plenary Session address at the $14^{\text {th }}$ Biennial CIGAR Conference, 2-3 September 2013, Birmingham, UK.

Lüder, K., \& Jones, R. (2003). Reforming governmental and budgeting in Europe. Germany: Fachverlag Moderne Wirtschaft.

Lukka, K. (2007). Management accounting change and stability: loosely coupled rules and routines in action. Management Accounting Research, 18, 76-101. 
Meyer, J. W. (1983). On the celebration of rationality: some comments on Boland and Pondy. Accounting, Organizations and Society, 8(2/3), 235-240.

Meyer, J. W., \& Rowan, B. (1977). Institutionalized organizations: formal structure as myth and ceremony. American Journal of Sociology, 83(2), 340-363.

Macintosh, N. B. (1985). The social software of accounting and information systems. Wiley.

Modell, S. (2003). Goals versus institutions: the development of performance measurement in the Swedish university sector. Management Accounting Research, 14(4), 333-359.

MoF (Ministry of Finance, Malta). (2013a). Accounting standards must become integral part of Malta's Financial Legislation. Press Release 23 April 2013.

MoF. (2013b). NSO provide necessary gauges for Government to guide the ship of State. Press Release 2 August 2013.

MoF. (2013c). Need for harmonized accrual based public sector accounting standards. Press Release 25 October 2013.

MoF. (2013d). Financial estimates 2014. Ministry of Finance, Valletta.

MoF. (2014a), Tender for a corporate financial management solution for the government of Malta (CT2225/2012). Department of Contracts, Floriana.

MoF. (2014b). Financial Estimates 2015. Ministry of Finance, Valletta.

MoF. (2015). Financial Estimates 2016. Ministry of Finance, Valletta.

Moll, J., Burns, J. \& Major, M. (2006). Institutional theory. In Hoque, Z. (Ed.), Methodological issues in accounting research: theories and methods (pp. 183-205) London: Spiramus.

Monsen, N., \& Näsi, S. (1998). The contingency model of governmental accounting innovations, a discussion. European Accounting Review, 7(2), 275-288.

Oliver, C. (1991). Strategic responses to institutional processes. The Academy of Management Review, 16(1), 145-179.

Ouda, H. A. G. (2011). A prescriptive model of the transition to accrual accounting in central government. International Journal of Government Financial Management, Virginia USA: International Consortium on Governmental Financial Management, X(1), pp.63-94.

PAC (Public Accounts Committee, Government of Malta). (2009, 2010). Minutes of Public Account Committee Meetings.

Pallot, J. (1995). Contextual variables underlying innovation in national budgeting, accounting and auditing: the case of New Zealand. Paper presented at the Vth CIGAR Conference, Paris.

Pollitt, C. (2000). Is the emperor in his underwear? An analysis of the impacts of public management reform. Public Management Review, 2(2), 181-199.

Pollitt, C., \& Bouckaert, G. (2004). Public management reform: a comparative analysis, 2nd edition. Oxford: Oxford University Press.

Powell, W. W. (1991). Expanding the scope of institutional analysis, in: Powell, W.W., DiMaggio, P.J., (Eds.) The new institutionalism in organizational analysis (pp. 183-203)Chicago IL: University of Chicago Press.

Powell, W. W., \& DiMaggio, P. J. (1991). The new institutionalism in organizational analysis. Chicago IL: University of Chicago Press.

Power, M., \& Laughlin, R. (1996). Habermas, law and accounting. Accounting, Organizations and Society, 21(5), 441-465.

Prior, L. (2003). Using documents in social research. London: Sage.

Rahaman, A., Lawrence, S., \& Roper, J. (2004). Social and environmental reporting at the VRA: Institutionalised legitimacy or legitimation crisis? Critical Perspectives on Accounting, 15(1), pp.35-56. 